\title{
Beneficial Role of Nigella Sativa Extracted Oil on the Hepato-toxic Effect of Ceftriaxone in Adult Male Albino Rat (Histological and Immuno-histochemical Study)
}

Original Article

\author{
Heba Osama Mohammed
}

Department of Human Anatomy and Embryology, Faculty of Medicine, Zagazig University, Zagazig, Egypt.

\begin{abstract}
Introduction: Ceftriaxone is a broad-spectrum cephalosporin with a hepatotoxic effect. Nigella sativa (Ns) has potent antioxidant effects, so it has a promising medicinal application.

Aim: To study the possible protective role of Nigella Sativa Extracted Oil against the Hepato-toxic Effect of Ceftriaxone in adult male albino rat.

Materials and Methods: Thirty two adult male albino rats had been divided into four groups with 8 rats allocated in each group: Group 1 (control group), Group 2 (Ns oil administrated): received Nigella sativa (NS) oil $2 \mathrm{ml} / \mathrm{kg}$ by gastric tube daily for 4 weeks, Group 3 (ceftriaxone treated): received ceftriaxone (360 mg/kg) (I.P) daily for 4 weeks and Group 4 (Ns oil and ceftriaxone treated group). At the last day of the experiment, the liver specimens of each animal were dissected carefully and were processed for light-microscopic examination.

Results: Ceftriaxone treated group revealed elevated level of liver enzymes that were relatively lower in ceftriaxone and Ns oil group. Histological examination of the liver of ceftriaxone treated group showed dilated congested central vein and sinusoids with hydropic degeneration of hepatocytes, while portal triad revealed dilated congested portal vein and dilated bile ducts surrounded by inflammatory cells. Additionally, abundant deposition of collagen was detected and increased expression of TNF $\alpha$ immune staining within hepatocytes and in lining of sinusoids. All these histological alterations were less marked in group (4) which received NS oil in combination with ceftriaxone.

Conclusion: Ns oil has a protective effect against liver injury resulted from ceftriaxone injection due to its antioxidant activities.
\end{abstract}

Key Words: Adult male rats, ceftriaxone, liver, Ns L oil, TNF $\alpha$.

Revised: 27 February 2020, Accepted: 26 March 2020.

Corresponding Author: Heba Osama Mohammed, MD, Department of Human Anatomy and Embryology, Faculty of Medicine, Zagazig University, Zagazig 44519, Egypt, Tel.: +0552369963, E-mail: yassin_mekkawy@yahoo.com

ISSN:2536-9172, June 2020, Vol. 4, No. 1

\section{INTRODUCTION}

One of the broad-spectrum cephalosporin is Ceftriaxone. It has effective action against both gramnegative and positive bacteria ${ }^{[1]}$. It has prolonged halflife, so it can be prescribed as a single daily dose ${ }^{[2]}$. The liver is often known as the "great chemical factory" of the body, where the body depends on it to synthesize, store and release many important proteins, nutrients, chemicals and to clear toxin from the body. Moreover, the liver is thought to be the metabolic transformation center of drugs and other toxins entering from the GIT. Ceftriaxone results in partial damage of hepatocytes which lead to transient elevation of some parameters as Alanine aminotransferase (ALT), Aspartate aminotransferase (AST), total bilirubin, moreover, transient lowering of albumin and Highdensity lipoprotein (HDL) concentrations ${ }^{[3]}$. Liver toxicity resulted from ceftriaxone starts to appear after 10 days from administration ${ }^{[4,5]}$. Nigella sativa Linn is one of the Ranunculaceae family and considered as a herbal plant. The seeds of that plant (black seed), are widely used to protect body against different diseases in the Middle and Far East. That plant has potent antioxidant effects, so it has a promising medicinal applications ${ }^{[6,7]}$. Nigella sativa extracted oil has different antioxidant compounds as, thymoquinone (TQ), thymol, and dithymoquinone ${ }^{[8,9]}$. The black seed, NS, contains about $30 \%$ of fixed oil. The oil extracts of NS and its major active ingredient, thymoquinone (TQ) have a lot of beneficial biological actions, as antioxidant activity ${ }^{[10,11]}$ and antiinflammatory ${ }^{[10]}$, and hepatoprotective roles ${ }^{[12]}$. Expanded information about the histopathological and biochemical changes of liver on administration of ceftriaxone can be of benefits to clinicians and their patients. The current work has been intended to assess the beneficial role of Nigella sativa extracted oil in prevention of hepatic alterations which could be precipitated by ceftriaxone in adult male albino rats. 


\section{MATERIALS AND METHODS}

\subsection{Material}

\subsubsection{Drugs}

- Ceftriaxone had been purchased from Novartis Pharma Company (Cairo, Egypt) and was liquefied in distilled water just prior to administration. Each vial contained 500mg and then dissolved in $5 \mathrm{ml}$ distilled water.

- $\quad$ NsL oil: was obtained from Isis Company (Egypt).

\subsubsection{Animals}

Thirty - two adult male albino rats (180-200 g) were got from animal house of Zagazig University. Rats were housed in a temperature $\left(22-24^{\circ} \mathrm{C}\right)$ and humidity $(50 \pm 5 \%)$ controlled room in which $12 \mathrm{~h}$ light/dark cycles were kept for one week before the beginning of the experiment. A standard diet and tap water were provided ad libitum. All rats were under human care in accordance to the guidelines of Zagazig University Ethical Committee of (ZU-IACUC).

\subsubsection{Experimental design}

The animals were randomly distributed as following:

Group 1 (control group): included 8 animals divided into:

Subgroup (a) as a negative control (4 rats), they were kept without injection.

Subgroup (b) as a positive control (4 rats) each animal was given $0.7 \mathrm{ml}$ of distilled water (vehicle for ceftriaxone) by intraperitoneal injection (I.P) daily for 4 weeks.

Group 2 (Ns oil administrated): included 8 animals, each animal received NsL oil $2 \mathrm{ml} / \mathrm{kg}$ BW by gastric tube daily for 4 weeks. The animals were fasted 2 hours before NsL oil administration ${ }^{[13]}$.

Group 3 (ceftriaxone treated): included 8 animals, each animal received ceftriaxone

$(360 \mathrm{mg} / \mathrm{kg})$ (I.P) daily for 4 weeks $(0.5-0.7 \mathrm{ml}$ for each animal) $)^{[14]}$.

Group 4 (NsL oil and ceftriaxone treated group): included 8 animals, each rat received combined oral doses of $\mathrm{NsL}$ oil $2 \mathrm{ml} / \mathrm{kg}$ and ceftriaxone $(360 \mathrm{mg} / \mathrm{kg}$ ) (I.P) for 4 weeks.

By the last day of planned duration of the experiment, each animal was anesthetized by intraperitoneal injection of $60 \mathrm{mg} / \mathrm{kg}$ sodium thiopental ${ }^{[15,16]}$, and Laparotomy had been performed, and the liver specimens were obtained carefully and were prepared for light-microscopic examination.

\subsection{Methods}

\subsubsection{Biochemical study}

Liver enzymes in animals' sera (AST and ALT) were considered as biochemical parameters for hepatic injury.
Blood samples were immediately collected, at the end of experiment, from rat tail vein and collected blood was incubated at $37^{\circ} \mathrm{C}$ until it clotted. Centrifugation was performed at $2000 \mathrm{rpm}$ to obtain separated serum and detect Alanine aminotransferase (ALT) and Aspartate aminotransferase (AST) level according to ${ }^{[17]}$.

\subsubsection{Histological study}

Hepatic specimens had been preserved in $10 \%$ neutral buffered formalin as a fixator and processed then embedded in paraffin. Sections of $5 \mu \mathrm{m}$ thickness had been put on slides, deparaffinized in xylene, and then stained with:

Hematoxylin and eosin (H\&E) and Mallory's trichrome (MT) stain according to ${ }^{[18]}$. Each slide was examined by light microscopy (LeicaICC50W) at the imaging Unit of the Anatomy Department.

Immunostaining for tumor necrosis factor alpha $(T N F \alpha)$

TNF $\alpha$ (Tumor Necrosis Factor alpha) gene encodes a multifunctional pro inflammatory cytokine. It is mostly produced by macrophages and involved in the regulation of many biological processes as, cell proliferation, differentiation, apoptosis, lipid metabolism, and coagulation. Immunohistochemistry (IHC) was performed by using TNF-alpha IHC Antibody (polyclonal, Abbiotec, San Diego, CA, USA) diluted at 1:80 in phosphatebuffered saline (PBS). The primary antibody was diluted in phosphate- buffered saline with a dilution of 1:50. The sections were incubated with the primary antibody overnight at $+4{ }^{\circ} \mathrm{C}$. Enough Biotinylated secondary antibodies were applied to cover specimen then the binding of the primary antibody was noticed by using a commercial avidinbiotinperoxidase detection system (DAKO, Carpenteria, USA). PBS was used instead of primary antibody to act as a negative control. Human mammary cancer sections were used as a positive control for (TNF $\alpha$ ). After that, the slides were stained with diaminobenzene (DAB) as the chromogen and counter stained with hematoxylin then slide dehydrated in 95\% ethanol, cleared in xylene then cover slips were mounted using two drops of DPX mounting medium ${ }^{[19]}$.

\subsubsection{Morphometric analysis}

For morphometrical analysis, eight rats were utilized per group by using image analyzer (the Image $\mathrm{J}$ software plugin) in Anatomy department - Zagazig University as follow:

H\&E-stained slides of liver specimen of different groups were analyzed to calculate the area percentage of hydropic degeneration of liver cells scattered in microscopic images captured at $400 \times$ in non-overlapped field. Mean value for each section was assigned. Each section was scored to 
estimate the degree of degenration as follows: 0 meant no hydropic degeneration, 1 meant $<25 \%, 2$ meant hydropic degeneration percent was between $25 \%$ and $50 \%$, and 3 for $>50 \%{ }^{[20]}$.

Sections stained with Mallory trichrome were morphometrically analyzed for area percent of collagen in non-overlapping microscopic areas under 400 high power fields. A mean of 15 readings was calculated from 5 subsequent sections from slides of each animal in each group.

TNF $\alpha$ immunohistochemical stained slides of each group were analyzed to estimate the area percentage of positive immune reaction for TNF $\alpha$ which was done after image splitting and was calculated at the objective lens of $40 x$.

\subsubsection{Statistical Analysis:}

The collected data were represented as mean \pm standard error(SE) for quantitative variables and analyzed statistically by using program of SPSS (SPSS Inc. Chicago, IL, USA). The results of all examined groups were compared by Oneway Analysis of Variance (ANOVA) followed by LSD test to compare statistical differences between the groups. $P$ value $\leq 0.05$ is considered statistically significant.

\section{RESULTS}

There was no mortality in rats of different groups

\subsection{Biochemical results (ALT and AST serum level):}

Measuring level of bo/th ALT and AST in serum of different groups showed non-significant difference between control group and NsL administrated group. In contrast, there was significant increase in their levels in serum of ceftriaxone treated group. Additionally, the group which treated with NsL oil in combination with ceftriaxone showed significant increase in their levels but significantly less than ceftriaxone treated group (Table.1. Fig.1A, 1B).

\subsection{Gross observation}

The liver of ceftriaxone treated group appeared pale brown and soft in consistency versus liver of other groups.

\subsection{Histopathological results}

\subsection{1. $H \& E$}

\section{Control group}

Examination of H\&E stained sections in liver of both control subgroups and NsL administrated group showed nonstructural difference. Their examination of them revealed that hepatic section is formed of cords of hepatocytes radiating around central vein. Hepatocytes had acidophilic cytoplasm and vesicular nucleus. Thin blood sinusoids radiated between them. Portal tract showed portal vein with thin wall and bile duct with cuboidal cell lining also were detected (Fig. 2A \& 2B).

\section{Control 3 (Ceftriaxone treated)}

Hepatic sections of group 3 revealed alteration of hepatic architecture around dilated congested central vein and dilated congested sinusoids in between hepatocytes. Most of liver cells around both central vein and portal vein represented hydropic degeneration of the cytoplasm which appeared as foamy and vacuolated cytoplasm. Some hepatocytes had darkly stained nuclei and others exhibited vesicular nuclei. The portal area revealed markedly dilated congested portal vein and dilated bile ducts surrounded by inflammatory cells (Fig. 3A \& 3B).

\section{Control 4 (Nigella+ ceftriaxone)}

Examination of H\&E stained sections in liver of NsL administrated in combination with ceftriaxone group showed preservation of normal structure of liver mostly. Hepatocytes had acidophilic cytoplasm and vesicular nucleus but some exhibited vacuolated cytoplasm and darkly stained nuclei. Thin blood sinusoids radiated between them. Portal tract with thin walled portal vein, bile duct with cuboidal cell lining and few inflammatory cells also were detected (Fig.4A \& 4B).

\subsubsection{Mallory trichrome staining}

Liver sections stained with Mallory trichrome of both control and NsL administrated groups showed minimal deposition of collagen fibers within portal area (Fig.5A) and around central vein (Fig.6A). However, collagen fibers were abundant within portal area of ceftriaxone treated group (Fig.5B) and around dilated central vein (Fig.6B) of same group. Collagen fibers were moderately deposited within portal area (Fig.5C) and around central vein (Fig.6C) in group administrated NsL oil in combination with ceftriaxone.

\subsubsection{TNFa immunstaining}

Liver sections of both control and NsL administrated groups showed minimal expression of TNF $\alpha$ in hepatocytes and within sinusoids (Fig.7A) while ceftriaxone treated group showed marked expression of TNF $\alpha$ within hepatocytes cytoplasm and in cytoplasm of lining cells of sinusoids which appeared dark brown (Fig.7B). The expression decreased markedly within hepatocytes and in lining of sinusoids of liver of group administrated NsL oil in combination with ceftriaxone (Fig.7C). 


\subsection{Morphometric results}

Scoring of hydropic degeneration area percent that affected the hepatocytes showed high scoring in group treated with ceftriaxone which was significantly higher than all other groups. On the other hand, on administration of NsL in combination with ceftriaxone, scoring decreased significantly but still higher than control groups (Table.2. Fig.8).
Results of morphometric analysis showed highly significant increase of both area percent of collagen and $\mathrm{TNF} \alpha$ immune staining in ceftriaxone treated group in comparison with control group. However, both area percent decreased significantly on administration of NsL oil in combination with ceftriaxone. Moreover, there was no significant difference between control group and NsL oil administrated group (Table.3. Fig. 9A \& B).

Table.1: Serum level of ALT and AST U/L of different groups

\begin{tabular}{lllll}
\hline Parameter Mean \pm SE & Group1(control) & Group 2 (Ns administrated) & Group 3 (ceftriaxone treated) & $\begin{array}{l}\text { Group 4 (NS oil and ceftriaxone } \\
\text { treated group) }\end{array}$ \\
\hline ALT U/L & $24.75 \pm 0.1783$ & $25.15 \pm 0.2027 \mathrm{NS}^{\mathrm{a}}$ & $35.98 \pm 0.2462 P<0.05^{\text {a\&b }}$ & $28.63 \pm 0.1916 P<0.05^{\mathrm{a}, \mathrm{b} \& \mathrm{c}}$ \\
AST U/L & $51.50 \pm 0.3185$ & $51.20 \pm 0.2228 \mathrm{NS}^{\mathrm{a}}$ & $91.46 \pm 0.3803 P<0.05^{\mathrm{a} \& \mathrm{~b}}$ & $63.98 \pm 0.1887 P<0.05^{\mathrm{a}, \mathrm{b} \& \mathrm{c}}$ \\
\hline
\end{tabular}

$\mathrm{NS}=$ non-significant $(P>0.05), P<0.05=$ statistically significant, $\mathrm{a}=$ versus group $1, \mathrm{~b}=$ versus group 2 , and $\mathrm{C}=$ versus group 3

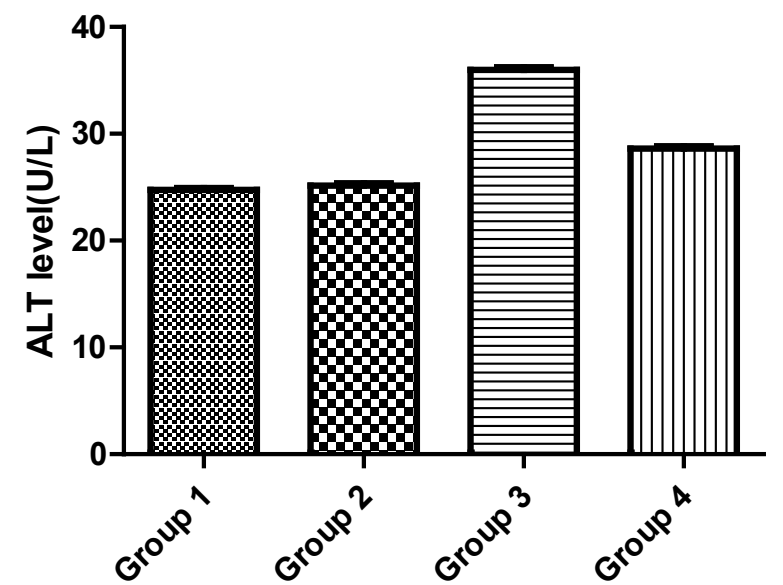

Fig.1.A.Serum level of ALT (U\L) in different groups

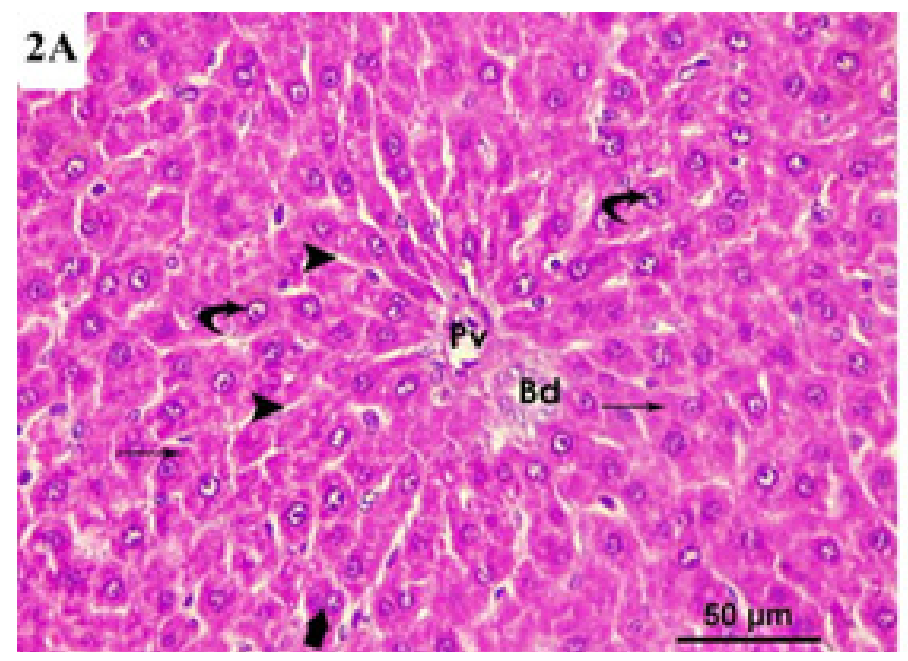

Fig. 2: A photomicrograph of a liver section of adult male rat of control group (2A) is showing portal area containing thin walled portal vein (PV) and bile duct (Bd) lined with cuboidal cells, (2B) is showing central vein (CV) with polygonal hepatocytes have acidophilic cytoplasm (thin arrow) and vesicular nucleus (curved arrow). Thin blood sinusoids (arrow head) radiating between hepatocytes cords and their lining endothelium are seen. Binucleated cells are also seen (thick arrow).
Fig.1.B: Serum level of AST $(U \backslash L)$ in different groups

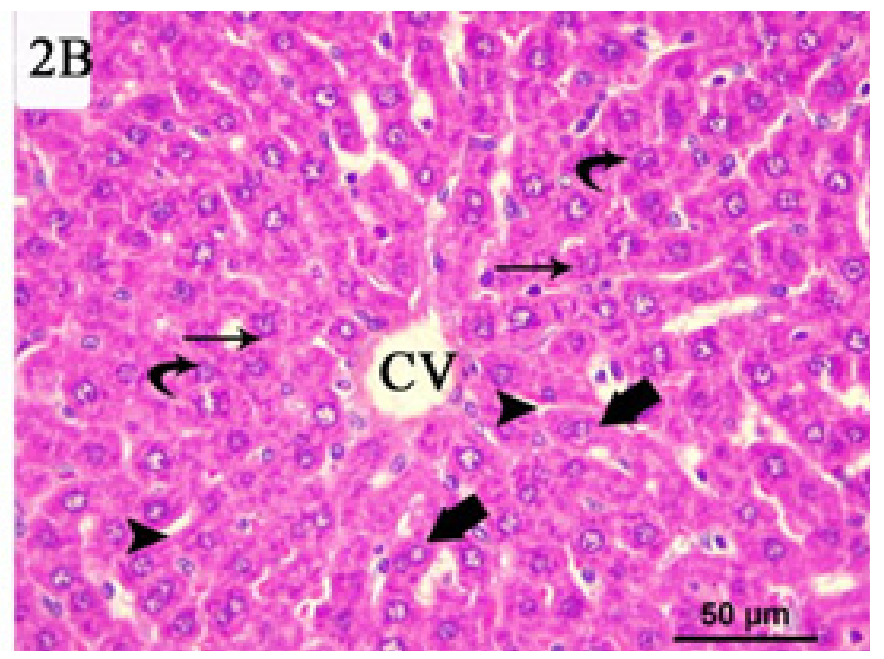

(H \& E x 400).

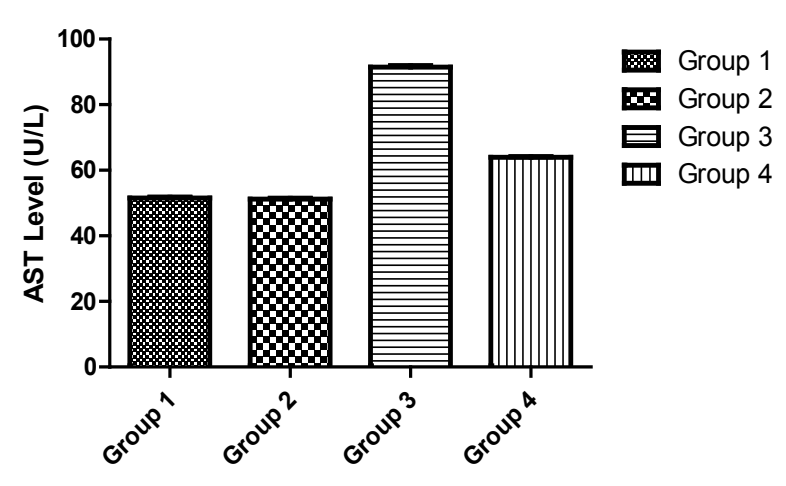



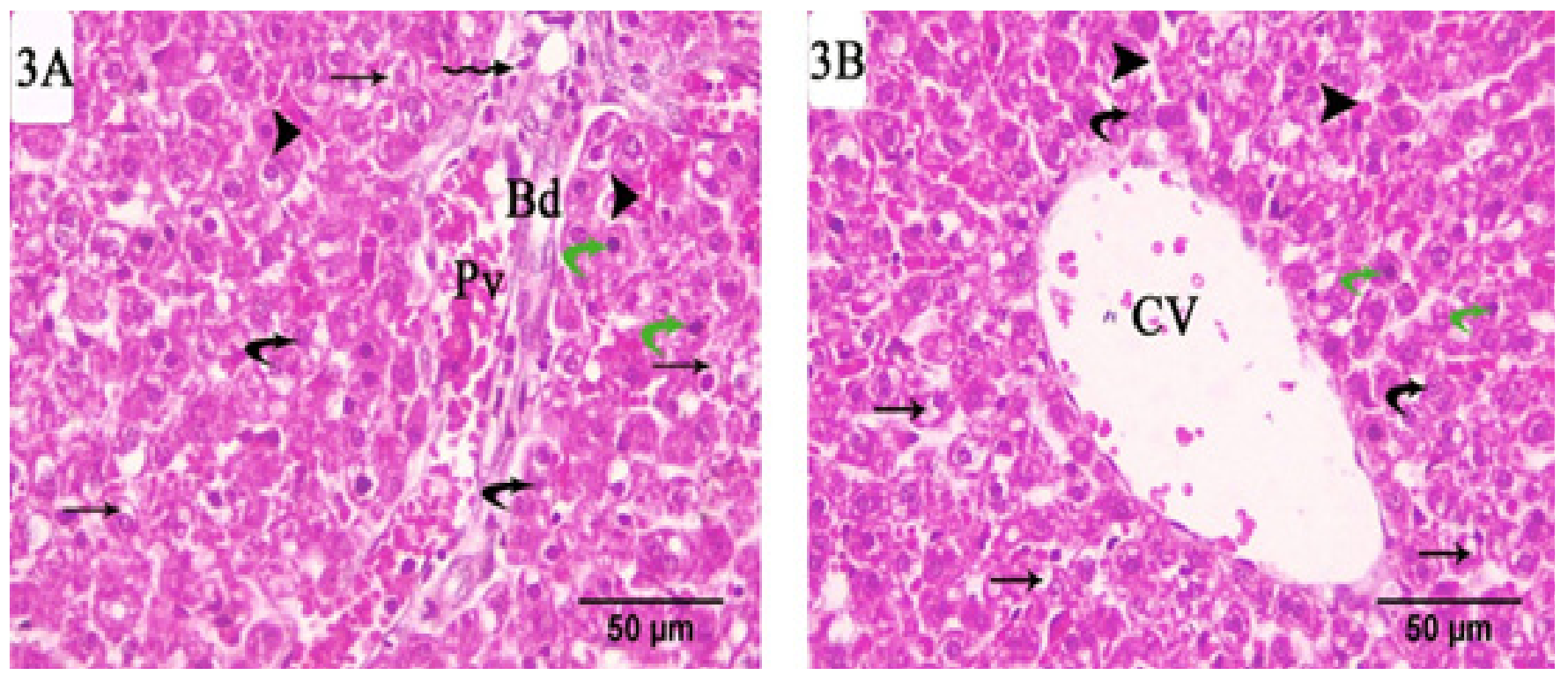

Fig.3: Photomicrographs of a liver section of adult male rat of group III, (3A) shows dilated congested portal vein (Pv), dilated bile duct (Bd) and surrounded by inflammatory cells (zigzag arrow). (3B) shows dilated central vein (CV). Hepatocytes exhibit vacuolated and foamy cytoplasm (thin arrow). Some have vesicular nuclei (curved arrow), others with dark stained nucleus (green curved arrow). Sinusoids appear dilated and congested (arrow head)

(H\&E X400).
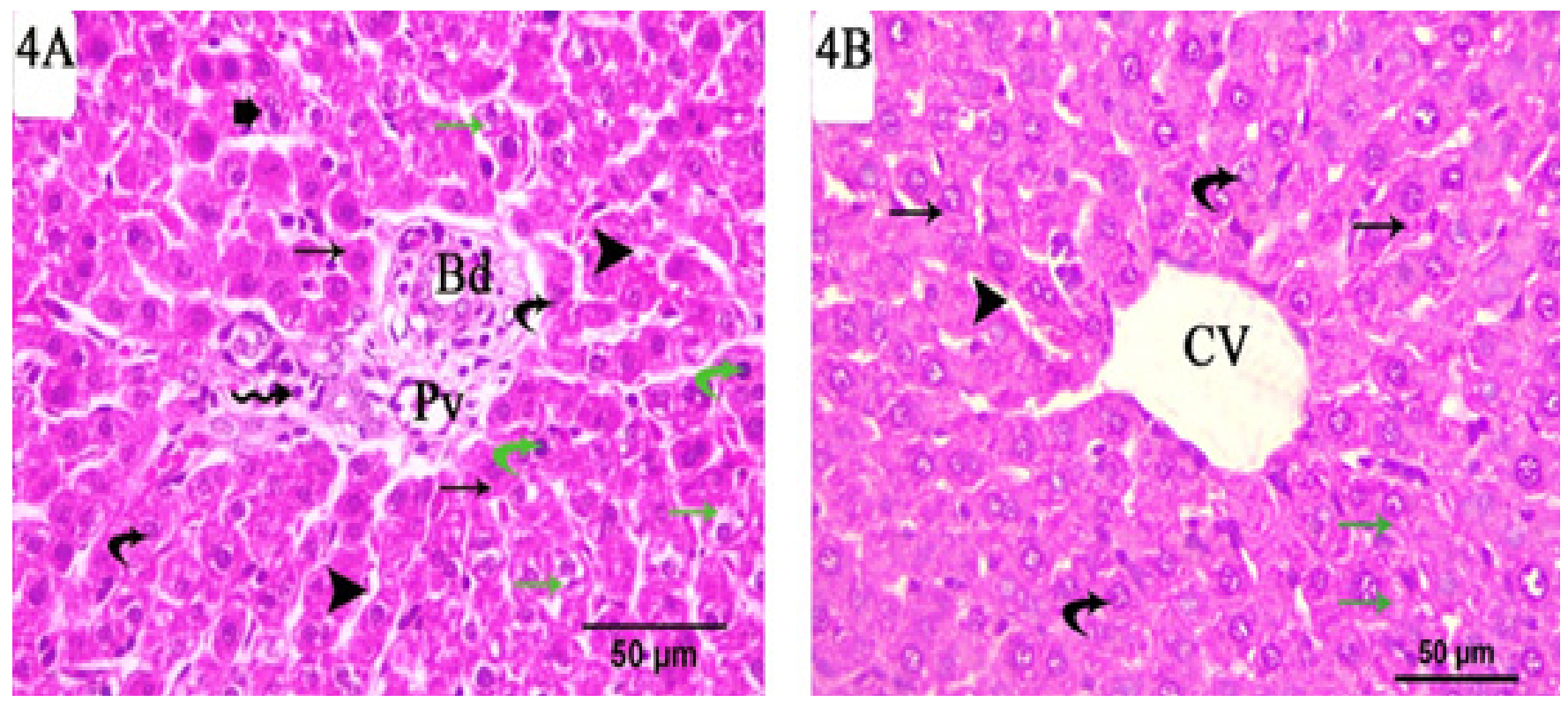

Fig.4: Photomicrographs of a liver section of adult male rat of group IV, (4A) portal area shows thin walled portal vein ( $\mathrm{Pv})$, bile duct (Bd) and surrounded by few inflammatory cells (zigzag arrow). (4B) shows dilated central vein (CV). Some hepatocytes exhibit acidophilic cytoplasm (thin arrow) and others exhibit vacuolated and foamy cytoplasm (thin green arrow). Some have vesicular nucleus (curved arrow), others with dark stained nucleus (green curved arrow). Sinusoids appear thin walled (arrow head). Binucleated cells are seen (thick arrow) (H\&E X400) 

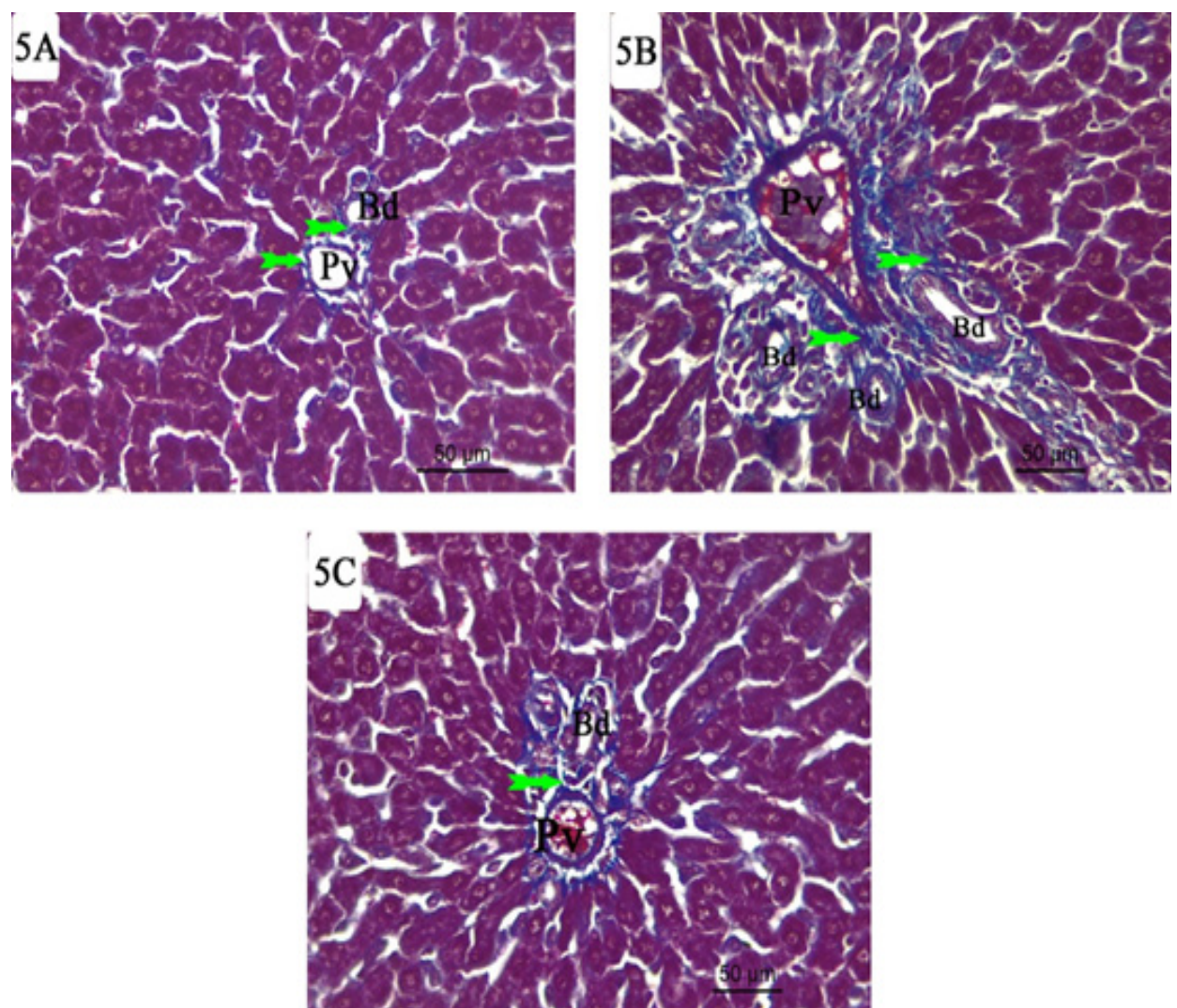

Fig.5: Aphotomicrograph of a liver section of adult male rat, (5A) control group shows minimal amount of collagen fibers (green tailed arrow) around bile duct $(\mathrm{Bd})$ and portal vein $(\mathrm{Pv})$. (5B) ceftriaxone treated group shows marked deposition of collagen fibers (green tailed arrow) around portal vein $(\mathrm{Pv})$ and bile ducts $(\mathrm{Bd})$. (5C) NS oil in combination with ceftriaxone treated group shows moderate deposition of collagen fibers (green tailed arrow) around portal vein (Pv) and bile ducts (Bd).

(Mallory trichrome X 400)
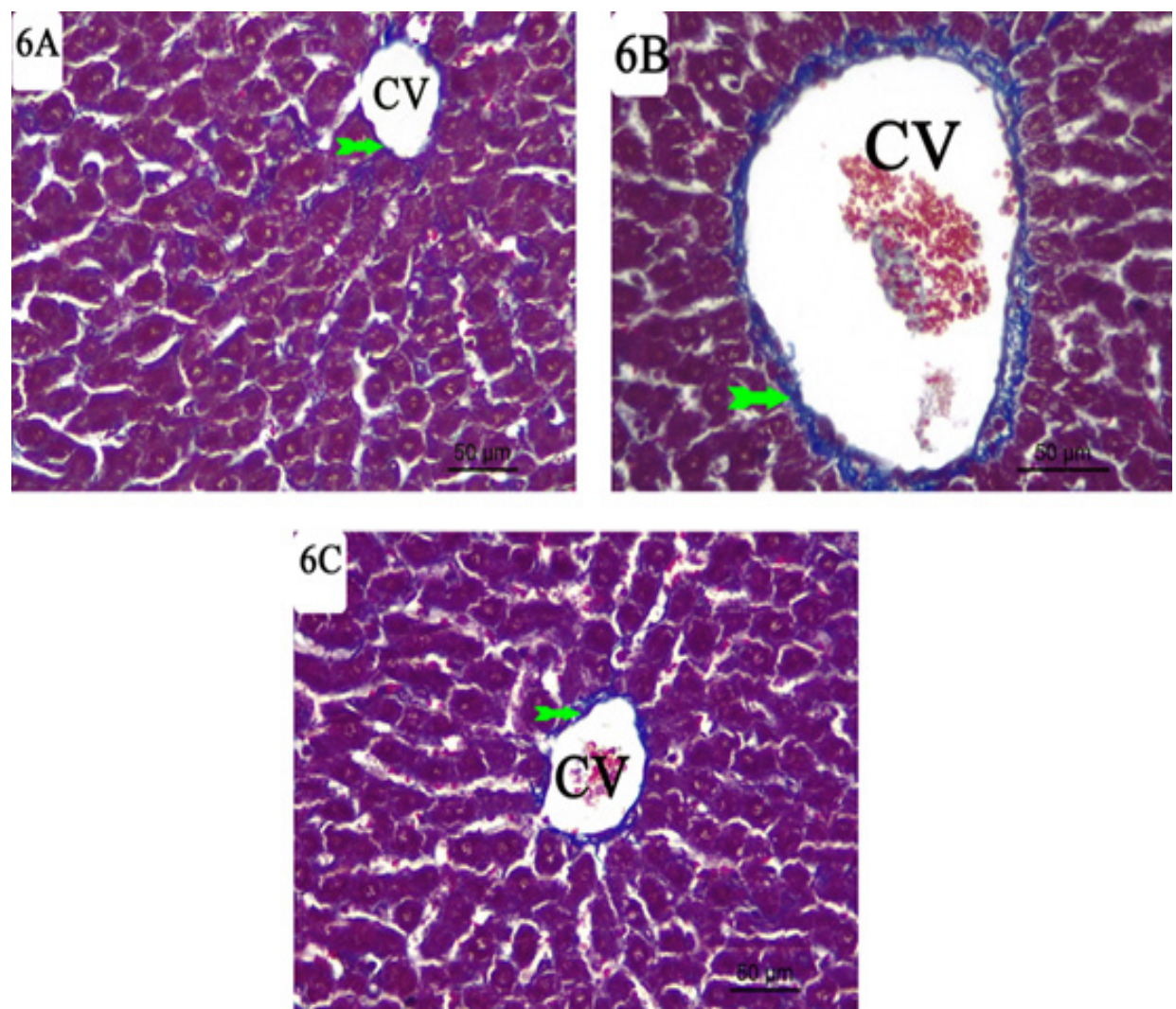

Fig.6: Aphotomicrograph of a liver section of adult male rat, (6A) control group shows minimal amount of collagen fibers (green tailed arrow) around central vein $(\mathrm{CV})$. (6B) ceftriaxone treated group shows marked deposition of collagen fibers (green tailed arrow) around dilated central vein (CV). (6C) NS oil in combination with ceftriaxone treated group shows moderate deposition of collagen fibers (green tailed arrow) around central vein (CV).

(Mallory trichrome X 400). 

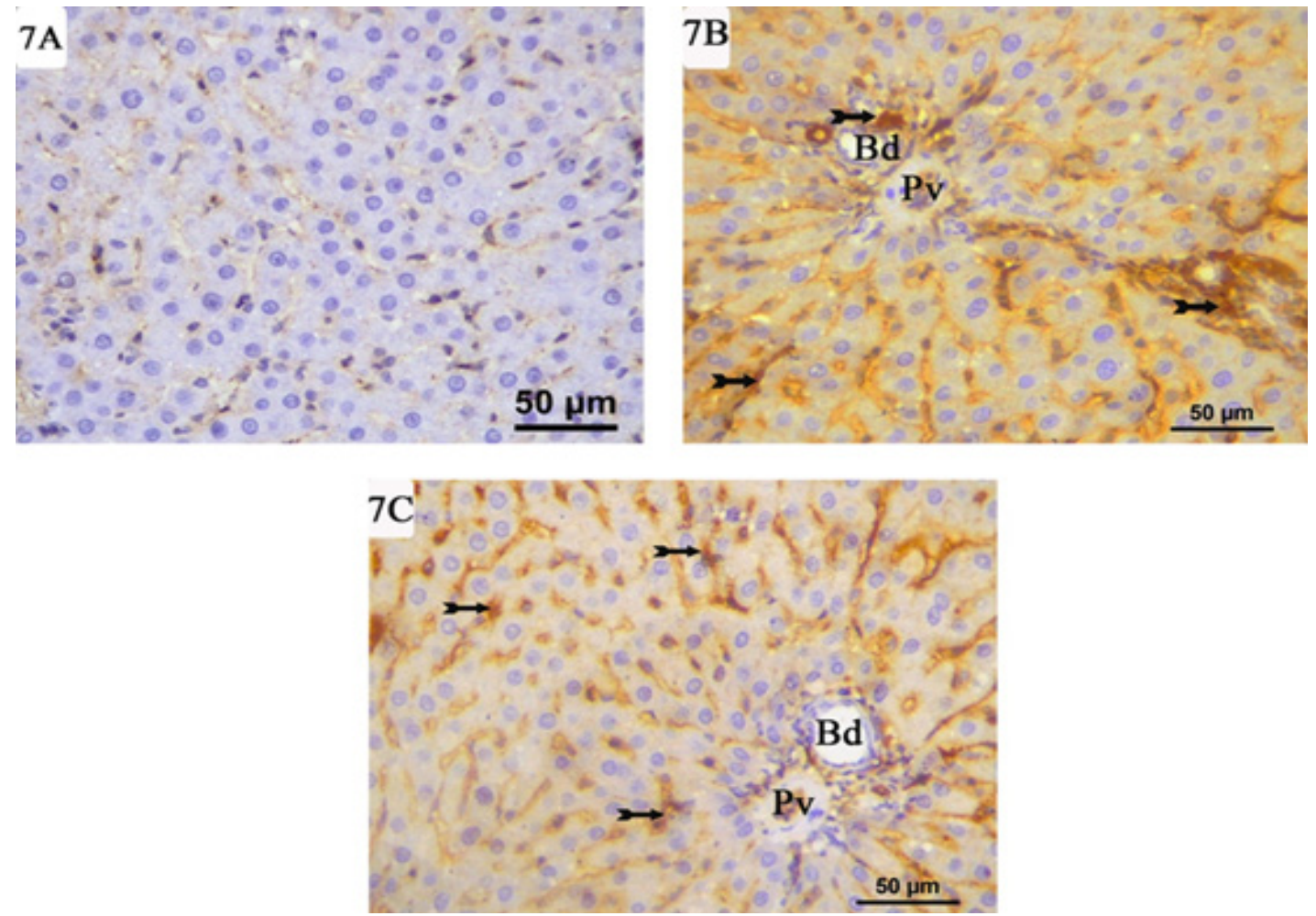

Fig.7: A photomicrograph of liver sections of adult male rat stained with TNF $\alpha$ immunostaining; (7A) group I shows minimal expression of TNF $\alpha$ in hepatocytes and within sinusoids. (7B) group III shows bile duct (Bd) and portal vein (Pv) with marked expression of TNF $\alpha$ within hepatocytes and in lining of sinusoids (tailed arrow). (7C) group IV shows portal vein ( $\mathrm{Pv})$ and bile duct $(\mathrm{Bd})$ with moderate expression of TNF $\alpha$ within hepatocytes and in lining of sinusoids (tailed arrow).

(TNF $\alpha$ immunstaining X400).

Table. 2: Score of hydropic degeneration of hepatocytes in different groups

\begin{tabular}{lllll}
$\begin{array}{l}\text { Parameter } \\
\text { Mean } \pm \mathrm{SE}\end{array}$ & Group 1 (control) & $\begin{array}{l}\text { Group 2 (Ns } \\
\text { administrated) }\end{array}$ & $\begin{array}{l}\text { Group3 (ceftriaxone } \\
\text { treated) }\end{array}$ & $\begin{array}{l}\text { Group 4 (NS oil and } \\
\text { ceftriaxone treated group) }\end{array}$ \\
\hline $\begin{array}{l}\text { Hydropic } \\
\text { degeneration } \\
\text { score }\end{array}$ & $0.5000 \pm 0.1890$ & $0.8750 \pm 0.2266 \mathrm{NS}^{\mathrm{a}}$ & $2.875 \pm 0.1250 P<0.001^{\mathrm{a} \& \mathrm{~b}}$ & $1.750 \pm 0.2500 P<0.001^{\mathrm{a}, \mathrm{b} \& \mathrm{c}}$ \\
\hline
\end{tabular}

Hydropic degeneration score was considered (0) for no changes, (1) for less than $25 \%$ affected cells, (2) for changes between $25 \%$ and $50 \%$, and (3)for more than 50\%. NS = non-significant $(P>0.05), P<0.05=$ statistically significant, $\mathrm{a}=$ versus group $1, \mathrm{~b}=$ versus group 2 , and $\mathrm{C}=$ versus group 3 .

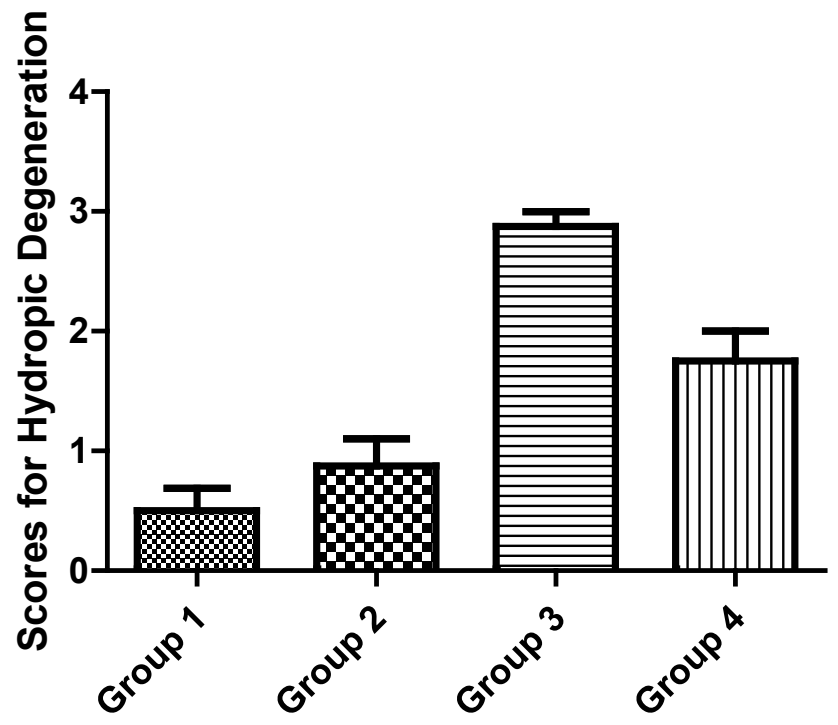

Fig.8: Score of hydropic degeneration of hepatocytes in different group 
Table. 3: Area percent of collagen and $\mathrm{TNF} \alpha$ immune staining in different groups

\begin{tabular}{lllll}
\hline $\begin{array}{l}\text { Parameter } \\
\text { Mean } \pm \text { SE }\end{array}$ & $\begin{array}{l}\text { Group 1 } \\
\text { (control) }\end{array}$ & $\begin{array}{l}\text { Group 2 }(\mathrm{Ns} \\
\text { administrated) }\end{array}$ & Group3 (ceftriaxone treated) & $\begin{array}{l}\text { Group 4 (NS oil and } \\
\text { ceftriaxone treated group) }\end{array}$ \\
\hline $\begin{array}{l}\text { Area percent } \\
\text { of collagen\% }\end{array}$ & $8.101 \pm 0.1173$ & $720 \pm 0.1784 \mathrm{NS}^{\mathrm{a}}$ & $27.23 \pm 0.8331 P<0.001^{\mathrm{a} \& \mathrm{~b}}$ & $20.27 \pm 0.2387 P<0.001^{\mathrm{a}, \mathrm{b} \& \mathrm{c}}$ \\
$\begin{array}{l}\text { Area percent } \\
\text { of TNF }\end{array}$ & $7.530 \pm 0.1548$ & $8.259 \pm 0.1316 \mathrm{NS}^{\mathrm{a}}$ & $67.98 \pm 3.926 P<0.001^{\mathrm{a} \& \mathrm{~b}}$ & $33.56 \pm 0.3248 P<0.001^{\mathrm{a}, \mathrm{b} \& \mathrm{c}}$ \\
\hline
\end{tabular}

$\mathrm{NS}=$ non-significant $(P>0.05), P<0.001=$ statistically highly significant, $\mathrm{a}=$ versus group $1, \mathrm{~b}=$ versus group 2 , and $\mathrm{C}=$ versus group 3 .

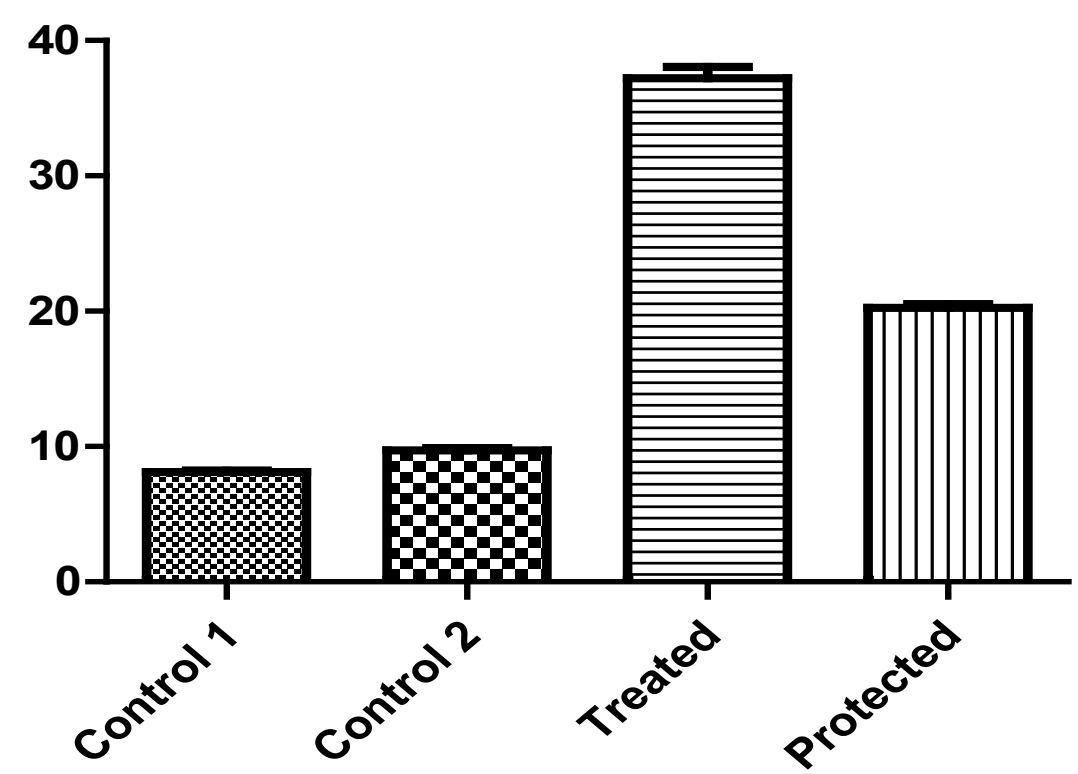

Fig.9A: Area percent of collagen in different group

\section{DISCUSSION}

Ceftriaxone is a well-known broad-spectrum antibiotic of third generation cephalosporin antibiotics ${ }^{[21]}$. Many evidences indicate that it can result in increase of the hepatic enzymes and hepatic insult as side effects ${ }^{[3]}$. Liver is believed to be the essential target for many toxicants as it has great effect in detoxification, transformation, and elemination of xenobiotics ${ }^{[22]}$.

In this study, elevations of ALT and AST serum activities were detected in rats treated with ceftriaxone than control groups. Johnkennedy et $a^{[23]}$ considered that AST and ALT were the most sensitive indicators in the diagnosis of liver injury. Results of El Sayed et al ${ }^{[3]}$ are in same line of this study results. However, administration of NsL. Oil in combination with ceftriaxone resulted in decrease of ALT and AST activities. Hamza, and Al-Harbi ${ }^{[24]}$ reported decrease of elevated liver enzymes in Ns oil administrated group in combination with paracetamol. Accordaningly, Elkhateeb et al ${ }^{[25]}$ mentioned that NsL.oil could protect liver against insult caused by tramadol by controlling the activities of the ultra-structures of hepatocytes, and standardizing the levels of liver enzymes.
In the current study, there was alteration of hepatic structure around dilated congested central vein and dilated congested sinusoids in between hepatocytes. Abdelhalim, \& Jarrarloudy ${ }^{[26]}$ reported that most of liver cells showed cytoplasmic hydropic degeneration appeared as foamy and vacuolated cytoplasm Swelling of hepatocytes could occur as a result of alterations of membranes function which in turn lead to excess inflow of water and $\mathrm{Na}+$ associated with leakage of lysosomal hydrolytic enzymes that resulted in cytoplasmic degeneration. The vacuolated cytoplasm of the hepatocytes of rats treated with GNPs could refer to acute and subacute liver insult. Moreover, Izunya et al ${ }^{[27]}$ put explanation of existence of vacuolated cytoplasm in cardiac cells by the generation of superoxide anions in response to oxidative stress that caused peroxidation of lipid. Accumulation of those products led to breakdown of some organelles and disturbance of membrane permeability. Additionally, oxidative stress led to consumption of adenosine triphosphate (ATP) and stoppage of the Na- K pump which resulted in cellular edema.

Present study demonstrated some hepatocytes had darkly stained nuclei and other liver cells had vesicular nuclei and foamy vacuolated cytoplasm. These findings supported by scoring to hydropic degenrations of hepatocytes which was 
significantly higher on treatment of ceftriaxone than all other groups. The portal area revealed that portal vein had dilated congested wall and dilated bile ducts surrounded by inflammatory cells. These findings are in consistence with Alhumaidha et $a l^{[14]}$ who found nearly complete lobular degeneration, on treatment with ceftriaxone, appeared as hydropic degeneration of liver cells and pyknosis of their nuclei. Additionally, ${ }^{[28]}$ reported that liver biopsy of animals treated with ceftriaxone demonstrated mixed inflammatory infiltrate in the lobule with mild central venulitis. Liver injury and liver inflammation resulted in release of cytokines by hepatic cells themselves, such as TNF- $\alpha$ and reactive oxygen species (ROS). These mediators could cause plasma membrane peroxidation and cell death due to necrosis or apoptosis ${ }^{[29,30]}$. Hepatic stellate cells (HSCs) were activated and become associated with the acquisition of pro-fibro genic and pro-inflammatory functions ${ }^{[31]}$

These pathological findings were less in group administrated Nsl in combination with ceftriaxone. In accordance, Alsemeh et $a l^{[20]}$ reported improvement in liver changes on administration of nigella in concomitant with GA3.

Present work detected normal distribution of collagen in control group sections that were stained with Mallory trichrome. These results are in consistence with the results of Alshawsh et al ${ }^{[32]}$. However, abundant deposition of collagen in liver sections of Ceftriaxone treated rats. These findings indicated the occurrence of fibrosis in hepatic tissue and confirmed by morphometric results of area percent of collagen as it was significantly higher than that of control one. This fibrosis of the liver had been explained by Bauer and Schuppan ${ }^{[33]}$, as they mentioned that the fibrosis was started by liver cell injury, which resulted in stimulation of Kupffer cells and followed by production of cytokines and growth factors. These factors stimulated stellate cells that in turn transformed into myofibroblastlike cells which deposit great amounts of connective tissue components. Moreover, administration of Ns oil decreased the percentage of collagen in liver sections of group 4 rats. In accordance, Saricicek et $a l^{[34]}$ reported liver sections of rats received Ns oil in their diet showed less fibrosis than other rats in their experiment in the same line, Wilson et al. ${ }^{[35]}$ detected decrease in liver and lung fibrosis and inflammation on administration of thymoquinone, the active component of nigella seeds.

TNF- $\alpha$ is mostly released by macrophages in inflammatory tissues and has been involved in angiogenesis during inflammation, wound repair, and growth of tumors $^{[36]}$. Liver sections that stained with TNF $\alpha$ immune staining revealed marked expression in group treated with ceftriaxone. The expression was highly significant than all other groups as it confirmed by morphometric analysis. These results were inconsistence with ${ }^{[37]}$ whose results detected high expression of TNF $\alpha$ found in hepatocytes and in liver sinusoids cells (macrophages and endothelial cells) in specimen of chronic hepatic disease. Proinflammatory TNF- $\alpha$ was released under effect of tissue injury by large number of infiltrating monocytes that secreted TNF- $\alpha^{[38]}$ $\mathrm{TNF} \alpha$ expression was significantly less in rats which administrated NsL in combination with ceftriaxone treatment than rats treated with ceftriaxone only. These findings supported by Norouzi et al.,${ }^{[39]}$ who reported that heart muscle of rats treated with LPS showed less TNFo expression on administration of NsL.

Additionally, Hammam et al.,${ }^{[37]}$ reported that ceftriaxone induced oxidative stress in liver as detected by decrease GSH and increased of MDA levels. Oxidative stress is one of causes that responsible for the production of proinflammatory cytokines as TNF- $\alpha$, interleukins 6 (IL-6) and 8 (IL-8), and adiponectin. These cytokines are produced by lymphocytes and Kupffer cells under effect of free radical-mediated mechanisms as they altered permeability of mitochondrial membrane and inhibited the respiratory chain $^{[40,41,42,43]}$

In the present work, adjuvant use of NsL. oil with ceftriaxone improved histopathological findings markedly. Develi et $a l^{[44]}$ reported that Ns oil intake resulted in improvement of histopathological alterations in liver tissue caused by ethanol administration. These results agreed with those of Barakat et $a l^{[45]}$, who reported that intake of of NsL.oil decreased the serum levels of liver and kidney injury markers. Additionally, Salem, and Altayeb, $(2017)^{[13]}$ reported ameliorated effect of Ns oil on degenerative changes induced in liver by cisplatin treatment, when it administrated in combination with cisplatin treatment, as there was significant improvement in the biochemical alterations regarding ALT that is more specific for liver. Same findings were detected by Gani and John ${ }^{[46]}$ as they suggested the possibility of Ns oil to protect hepatocytes and so decrease the leakage of liver enzymes. Moreover, El-kott et al., ${ }^{[47]}$ reported that Ns oil treated group showed nearly normal hepatic sections with normal hepatocytes. Lipid peroxidation was claimed to induce destruction and damage to cell membranes which in turn resulted in alteration in membrane permeability and fluidity and promote protein degradation in mice ${ }^{[48]}$. Gökce et al ${ }^{[49]}$ reported that both the NS oil and TQ inhibit lipid peroxidation in liposomes. Additionally, NsL.oil caused reduction of lipid peroxidation in liver and kidney cells and resulted in elevation of hepatic and kidney antioxidant enzyme content. Khozoie et al, ${ }^{[50]}$ demonstrated that NsL could keep the catalase activity, glutathione peroxidase, and glutathione-S-transferase. Additionally, it could inhibit microsomal lipid peroxidation.

\section{CONCLUSION}

The obtained results of the current work revealed that NsL.oil has a partial protective role against hepatic 
injury that resulted from ceftriaxone injection due to its antioxidant activities. Further, clinical researches are needed to confirm this role.

\section{ABBEREVIATION:}

Nigella sativa Linn (NsL)

thymoquinone (TQ)

Alanine aminotransferase (ALT)

Aspartate aminotransferase (AST)

tumor necrosis factor alpha $(\mathrm{TNF} \alpha)$

\section{CONFLICT OF INTEREST}

There are no conflicts of interest.

\section{REFERENCES}

1. Raghunath, M. A. L. A. T. H. I., \& Bakal, S. H. E. E. T. A. L. (2013). Formulation and evaluation of a fixed dose combination of ceftriaxone disodium and ornidazole. Int J Pharm Life Sci, 5, 750-756.

2. Elsayed, M. G., Elkomy, A. A., \& Aboubakr, M. H. (2011). Effect of ceftriaxone on isolated gastrointestinal, tracheal and uterine smooth muscles. International Journal of Pharmaceutical Sciences and Research, 2(9), 2347.

3. El-Sayed, M. G. A., Elkomy, A. A., \& Aboubakr, M. H. (2011). Hepatotoxic Evaluation in Albino Rats Exposed to Ceftriaxone. Asian Journal of Pharmaceutical \& Biological Research(AJPBR), 1(2).

4. Simmons, C. (2002). Beware: antibiotic-induced hepatotoxicity is rare but deadly.

5. Vial T, Biour M, Descotes J, Trepo C. Antibioticassociated hepatitis: update from 1990. Ann Pharmacother 1997;31:204-20.

6. Gali-Muhtasib, H., El-Najjar, N., \& SchneiderStock, R. (2006). The medicinal potential of black seed (Nigella sativa) and its components. Advances in Phytomedicine, 2, 133-153.

7. Alenzi, F. Q., Alsakran Altamimi, M. A., Kujan, O., Tarakji, B., Tamimi, W., Bagader, O., ... \& Al-Swailmi, F. (2013). Antioxidant properties of Nigella sativa. J Mol Genet Med, 7(77), 1747 0862 .

8. Lutterodt, H., Luther, M., Slavin, M., Yin, J. J., Parry, J., Gao, J. M., \& Yu, L. L. (2010). Fatty acid profile, thymoquinone content, oxidative stability, and antioxidant properties of cold- pressed black cumin seed oils. LWT-Food Science and Technology, 43(9), 1409-1413.

9. Bourgou, S., Pichette, A., Marzouk, B., \& Legault, J. (2012). Antioxidant, anti-inflammatory, anticancer and antibacterial activities of extracts from Nigella sativa (black cumin) plant parts. Journal of Food Biochemistry, 36(5), 539-546.

10. Salem, M. L. (2005). Immunomodulatory and therapeutic properties of the Nigella sativa L. seed. International immunopharmacology, 5(1314), 1749-1770.

11. Hamdy, N. M., \& Taha, R. A. (2009). Effects of Nigella sativa oil and thymoquinone on oxidative stress and neuropathy in streptozotocin-induced diabetic rats. Pharmacology, 84(3), 127-134.

12. Al-Ghamdi, M. S. (2003). Protective effect of Nigella sativa seeds against carbon tetrachlorideinduced liver damage. The American journal of Chinese medicine, 31(05), 721-728.

13. Salem, M. M., \& Altayeb, Z. M. (2017). Light and Electron Microscopic Study on the Possible Protective Effect of Nigella Sativa Oil on Cisplatin Hepatotoxicity in Albino Rats. Egyptian Journal of Histology, 40(1), 68-79.

14. Alhumaidha, K. A., El-Awdan, S. A., El-Iraky, W. I., \& Ezz-El-Din, S. (2014). Protective effects of ursodeoxycholic acid on ceftriaxone-induced hepatic injury in rats. Bulletin of Faculty of Pharmacy, Cairo University, 52(1), 45-50.

15. Carpenter, J.W., editor (2005) . Exotic Animal Formulary. 3rd Ed. St. Louis: Elsevier Saunders.

16. Fish, R.E., Brown M.J., Danneman P.J., Karas A.Z., editors (2008). Anesthesia and Analgesia in Laboratory Animals. 2nd Ed. New York: Academic Press.

17. Thomas, L. (1998). Alanine aminotransferase (ALT), Aspartate aminotransferase (AST). Clinical Laboratory Diagnostics. 1st ed. Frankfurt: TH-Books Verlagsgesellschaft, 2, 55-65.

18. Bancroft, J. D., \& Gamble, M. (Eds.). (2008). Theory and practice of histological techniques. Elsevier health sciences.

19. Kim, S. H., Kim, K., Ahn, J. H., \& Chang, H. K. (2011). Increased expression of tumor necrosis factor-alpha in the rat hippocampus after acute homocysteine administration. Journal of epilepsy research, 1(1), 6 . 
20. Alsemeh, A. E., Moawad, R. S., \& Abdelfattah, E. R. (2019). Histological and biochemical changes induced by gibberellic acid in the livers of pregnant albino rats and their offspring: ameliorative effect of Nigella sativa. Anatomical science international, 94(4), 307-323.

21. Himanshu, R., Kumar Vinay, B. M., Sharadamma, K. C., \& Radhakrishna, P. M. (2012). Comparative study of antimicrobial activity of ceftriaxone in combination with sulbactam and tazobactam using disc diffusion method. IRJP, 3(05), 331-334.

22. Sakr, S. A., Okdah, Y. A., \& El-Abd, S. F. (2003). Gibberellin A3 induced histological and histochemical alterations in the liver of albino rats. Science Asia, 29, 327-31.

23. Johnkennedy, N., Adamma, E., Austin, A., \& Chukwunyere, N. E. (2010). Alterations in biochemical parameters of Wister rats administered with sulfadoxine and pyrimethamine (Fansidar R). Al Ameen Journal of Medical Sciences, 3(4), 317 321.

24. Hamza, R. Z., \& Al-Harbi, M. S. (2015). Amelioration of paracetamol hepatotoxicity and oxidative stress on mice liver with silymarin and Nigella sativa extract supplements. Asian Pacific Journal of Tropical Biomedicine, 5(7), 521-531.

25. Elkhateeb, A., El Khishin, I., Megahed, O., \& Mazen, F. (2015). Effect of Nigella sativa Linn oil on tramadol-induced hepato-and nephrotoxicity in adult male albino rats. Toxicology reports, 2, 512519.

26. Abdelhalim, M. A. K., \& Jarrar, B. M. (2011). Gold nanoparticles induced cloudy swelling to hydropic degeneration, cytoplasmic hyaline vacuolation, polymorphism, binucleation, karyopyknosis, karyolysis, karyorrhexis and necrosis in the liver. Lipids in Health and Disease, 10(1), 166.

27. Izunya, A. H. M., Nwaopara, A. O., Ayanwu, L. C., Odike, M. A., Oaikhena, G. A., Bankole, J. K., \& Okhiai, O. (2011). Histological studies of the cardiotoxicity of artesunate in Wistar rats.

28. Peker, E., Cagan, E., \& Dogan, M. (2009). Ceftriaxone-induced toxic hepatitis. World journal of gastroenterology: WJG, 15(21), 2669.

29. Buzzetti, E., Pinzani, M., \& Tsochatzis, E. A. (2016). The multiple-hit pathogenesis of non-alcoholic fatty liver disease (NAFLD). Metabolism, 65(8), 1038-1048.
30. Brunt, E. M., Wong, V. W. S., Nobili, V., Day, C. P., Sookoian, S., Maher, J. J., ... \& Rinella, M. E. (2015). Nonalcoholic fatty liver disease. Nature reviews Disease primers, 1(1), 1-22.

31. Diehl, A. M., Li, Z. P., Lin, H. Z., \& Yang, S. Q. (2005). Cytokines and the pathogenesis of nonalcoholic steatohepatitis. Gut, 54(2), 303-306.

32. Alshawsh, M. A., Abdulla, M. A., Ismail, S., \& Amin, Z. A. (2011). Hepatoprotective effects of Orthosiphon stamineus extract on thioacetamideinduced liver cirrhosis in rats. Evidence-based complementary and alternative medicine, 2011.

33. Bauer, M., \& Schuppan, D. (2001). TGF $\beta 1$ in liver fibrosis: time to change paradigms?. FEBS letters, 502(1-2), 1-3

34. Saricicek, E., Tarakcioglu, M., Saricicek, V., Gulsen, M. T., Karakok, M., Baltaci, Y., \& Taysi, S. (2014). Effect of Nigella sativa on experimental liver fibrosis.

35. Wilson, H., Carvalho, B., Granot, M., \& Landau, R. (2013). Temporal stability of conditioned pain modulation in healthy women over four menstrual

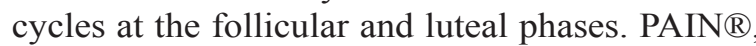
154(12), 2633-2638.

36. Mantovani, A., Schioppa, T., Porta, C., Allavena, P., \& Sica, A. (2006). Role of tumor-associated macrophages in tumor progression and invasion. Cancer and Metastasis Reviews, 25(3), 315-322.

37. Hammam, O., Mahmoud, O., Zahran, M., Sayed, A., Salama, R., Hosny, K., \& Farghly, A. (2013). A possible role for TNF- $\alpha$ in coordinating inflammation and angiogenesis in chronic liver disease and hepatocellular carcinoma. Gastrointestinal cancer research: GCR, 6(4), 107.

38. 38. Wheelhouse, N. M., Chan, Y. S., Gillies, S. E., Caldwell, H., Ross, J. A., Harrison, D. J., \& Prost, S. (2003). TNF- $\alpha$ induced DNA damage in primary murine hepatocytes. International journal of molecular medicine, 12(6), 889-894.

39. Norouzi, F., Abareshi, A., Asgharzadeh, F., Beheshti, F., Hosseini, M., Farzadnia, M., \& Khazaei, M. (2017). The effect of Nigella sativa on inflammation-induced myocardial fibrosis in male rats. Research in pharmaceutical sciences, 12(1), 74 .

40. Braunersreuther, V., Viviani, G. L., Mach, F., \& Montecucco, F. (2012). Role of cytokines and 
chemokines in non-alcoholic fatty liver disease. World journal of gastroenterology: WJG, 18(8), 727.

41. Buechler, C., Wanninger, J., \& Neumeier, M. (2011). Adiponectin, a key adipokine in obesity related liver diseases. World journal of gastroenterology: WJG, 17(23), 2801.

42. Hijona, E., Hijona, L., Arenas, J. I., \& Bujanda, L. (2010). Inflammatory mediators of hepatic steatosis. Mediators of inflammation, 2010.

43. Noronha, B. T., Li, J. M., Wheatcroft, S. B., Shah, A. M., \& Kearney, M. T. (2005). Inducible nitric oxide synthase has divergent effects on vascular and metabolic function in obesity. Diabetes, 54(4), 1082-1089.

44. Develi, S., Evran, B., Betul Kalaz, E., KoçakToker, N., \& Erata, G. O. (2014). Protective effect of Nigella sativa oil against binge ethanol-induced oxidative stress and liver injury in rats. Chin J Nat Med, 12(7), 495-9.

45. Barakat, M. K., Oda, N. R., Bayoumy, F. A., \& Bayoumy, F. A. (2010). Effect of Nigella sativa on Carbon Tetrachloride and Paracetamol Induced hepatotoxicity: Role of Antioxidant Enzymes and Cytokines.

46. Gani, M. S., \& John, S. A. (2013). Evaluation of hepatoprotective effect of Nigella Sativa L. Int J Pharm Pharm Sci, 5(4), 428-30.
47. El-kott, A. F., Kandeel, A. A., El-Aziz, S. F. A., \& Ribea, H. M. (2013). The Histopathological, Immunohistochemical And Ultrastructural Alterations Following Administration Of Nigella Sativa In Rats Hepatocellular Carcinoma. Cancer Therapy, 9.

48. El-Megharbel, S. M., Hamza, R. Z., \& Refat, M. S. (2014). Preparation, spectroscopic, thermal, antihepatotoxicity, hematological parameters and liver antioxidant capacity characterizations of $\mathrm{Cd}$ (II), $\mathrm{Hg}$ (II), and $\mathrm{Pb}$ (II) mononuclear complexes of paracetamol anti-inflammatory drug. Spectrochimica Acta Part A: Molecular and Biomolecular Spectroscopy, 131, 534-544.

49. Gökce, E. C., Kahveci, R., Gökce, A., Cemil, B., Aksoy, N., Sargon, M. F., ... \& Kahveci, O (2016). Neuroprotective effects of thymoquinone against spinal cord ischemia-reperfusion injury by attenuation of inflammation, oxidative stress, and apoptosis. Journal of Neurosurgery: Spine, 24(6), 949-959.

50. Khozoie, C., Borland, M. G., Zhu, B., Baek, S., John, S., Hager, G. L., ... \& Peters, J. M. (2012). Analysis of the peroxisome proliferator-activated receptor- $\beta / \delta(\mathrm{PPAR} \beta / \delta)$ cistrome reveals novel coregulatory role of ATF4. BMC genomics, 13(1), 665. 
الملخص العربى

الدور المفيد للزيث المستخلص من النيجيلا ساتيفا على التأثير السام للسيفترياكسون على الكبد في

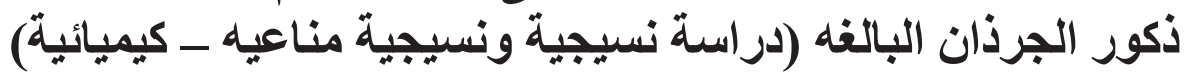

\section{هبd (سامه محمد}

\section{قسم التشريح الادمي والاجنه ، كلية الطب البشري،جامعة الزقازيق}

المقدمة: سيفترياكسون هو السيفالوسبورين واسع المدى له تأثثير سام على الكبد. نيجيلا ساتيفا لها تأثثيرات مضادة للأكسدة قوية

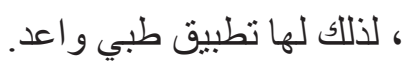
الهدف من العمل: دراسة الدور الوقائي المحتمل لزيت نايجيلا ساتيفا للتانير السمي للسيفترياكسون على الكبد في الجرذ الذكري البالغ. المواد والطرق: تم تقسيم اثثنين وثثلاثين من ذكور الجرذان البيضاء البالغة إلى أربع مجموعات مع تخصيص ^ م فئران في كل

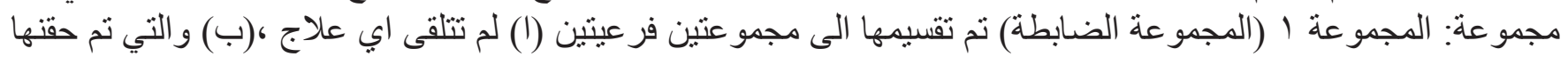

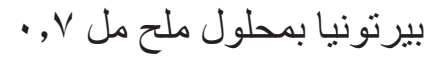

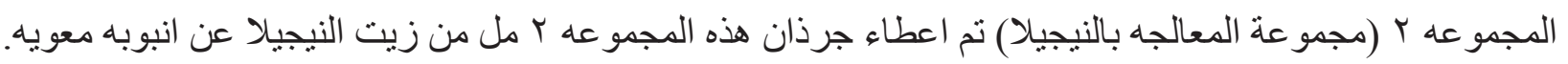

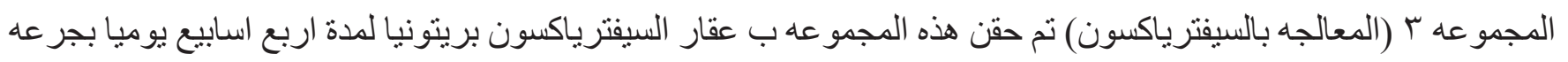

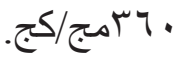

$$
\text { المجموعه ؛ (المعالجه بالنيجيلا مع السيفترياكسون). }
$$

في اليوم الاخير من التجربه تم اخذ عينات دم لقياس انزيمات الكبد و اخذ عينات الكبد بعنايه وتم معالجتها لفحصها بالميكرسكوب الضوئي. النتائج: كثنفت نتائج المجمو عه المعالجه بالسيفترياكسون عن ارتفاع في انزيمات الكبد ولكنها اقل ارتفاعا في المجمو عه التي

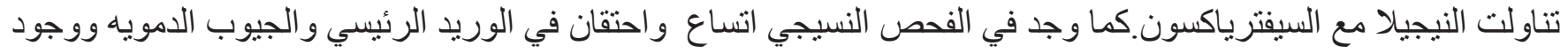

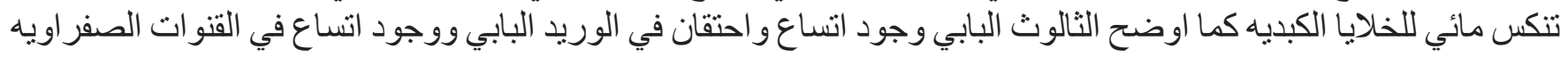

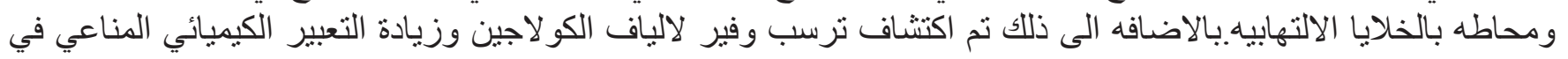

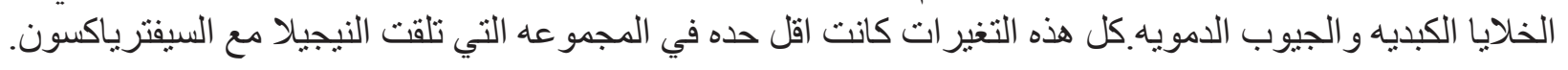

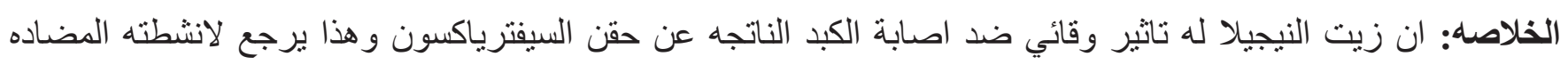

